\title{
Contribution of Onion Seed Production to Poverty Reduction: A Case Study of Malakand Division, Pakistan
}

\author{
IKRAM SAEED, MUHAMMAD ZUBAIR ANWAR, and KHALID MEHMOOD KHOKAR
}

\section{INTRODUCTION}

According to the latest estimates, roughly one-third of the total population of the developing countries live in poverty, majority of which are rural inhabitants (as reported 35 percent of the Pakistani rural mass). In Pakistan, the income distribution has worsened in the rural areas while it has marginally improved in urban areas during the period 1979 through 1996-97 [Pakistan (2001)]. The rural poverty is continuously feeding unemployment through migration of unskilled people to the urban areas. Poverty reduction is a priority area for Pakistan. The government is taking measures for addressing problems of the poor who are the most vulnerable amongst the different socioeconomic groups. Poverty alleviation is the main focus of the government in addition to develop physical infrastructure in rural areas and remove income disparities between income groups and regions.

The government of Pakistan has initiated measures to poverty reduction through establishing number of institutions namely Pakistan Poverty Alleviation Fund, Micro-credit Bank (Khushali Bank), Pakistan Baitual Mal, Income Safety Nets, and launching Khushal Pakistan Programme and Food Support Programme. All these programmes are aiming at helping poor and hungry people by providing them food for temporary relief and micro credit for initiating sustainable economic activities. Since the majority of our population is living in rural areas, so the government is diverting more resources to improve the access for rural services and encourage greater participation in economic activities through creating employment opportunities. The programmes in education, health and population sectors have been specifically designed to extend socioeconomic opportunities to rural poor. The

Ikram Saeed, Muhammad Zubair Anwar, and Khalid Mehmood Khokar are, respctively Director, Scientific Officer, and Senior Scientific Officer at the Pakistan Agricultural Research Council, Islamabad. 
government has started self employment schemes for both rural and urban destitute wherein loans are provided to unemployed people and skilled professionals for starting agricultural activities at their villages in small and medium enterprises like, poultry farming, bee keeping, growing fruits and cut flowers and installing agrobased industries.

\section{Background}

Accelerating agricultural growth is one of the priority issues of Pakistan as a complement to poverty reduction. High value crop production has paramount importance to meet the national food and cash needs through increasing net income of the poor and non-poor rural community, but also produce surplus commodities either to earn valuable foreign exchange or save it. In order to make significant dent in reducing poverty; a nation's people must first have enough to eat. When people have access to the food, they need to be strong and active participants in society. Of course, agriculture alone cannot end poverty. The economic history of nations tells that the tale of a continuous flow of workers out of agriculture into growing sectors such as industry. The process of industrialisation takes time. In the interim, improvement in agricultural productivity will put more food into local markets and encourage growth. It will also prevent the urban migration that plagues cities' social services and infrastructure, and thwart rural advancement.

Government of Pakistan has taken a series of steps for improving farm income and alleviating poverty, via adopting effective and conducive policy measures and technology led development [Pakistan (2001)]. Land supply ratio to a tiller is very limited in Malakanad Division, NWFP of Pakistan, so the possibility of expanding more area under crops, in general, is limited due to the present scenario of cultivated land and suitable irrigation water resources available in the region as well as country. The best alternative strategy is to adopt the land augmenting (intensive agriculture) options through utilising the recommended as well as economically feasible technologies that are simple and easy to adopt by the users. There are instances where the uses of divisible technologies, as the case of healthy and pure seed, are significantly contributing towards the higher productivity of the targeted crops. Presently, the use of certified seed has been catching up reasonably well. The private companies are campaigning to promote the sale of quality seed by adopting aggressive marketing tactics. Progressive farmers have also played very significant role in propagating the use of improved seeds. The present scenario of using certified seed is mainly true in Pakistan for major crops viz., cotton, maize, wheat, rice, and sugarcane. Still, the seed industry has not focused and promoted the use of certified seed for other crops. These crops can provide better returns to the farming community if certified seed is used. This is, in general, true for all crops, but in particular, it is true for onion seed due to the specific physiological architecture of the crop. 
A recent study carried out in the farming economy of Malakand Division, NWFP by a multidisciplinary team comprises of social and biological scientists from PARC, Federal Seed Certification and Registration Department (FSC\&RD) and Project for Horticultural Promotion (PHP), NWFP that registered a significant contribution in terms of quality onion seed production. As a result, it increased the growers net income, saved the valuable foreign exchange incurred on the import of the onion seed and increased the employment opportunities for the landless and owner household families [Saeed and Nasir (2001)]. In general, the country population including rural and urban falls in different income brackets where the distribution of poverty incidence to the tune of 34.8 percent and 25.9 percent occurs respectively [Pakistan (2001)].

Why in this study, the onion seed production venture is taken as a precedent of successful case contributing towards arresting the poverty strength. As discussed earlier, the economic significance of onion seed production but its' bulb production, being used as vegetables for consumption purposes, can not be denied due to its diversified uses in our daily life as a diet and health food. Health research on onion products has proved that it has medicinal importance consisting of diet ingredients that help in preventing heart related diseases and uses for other ailments. It is rich in phosphorus, calcium and carbohydrates. It is one of the important condiments widely used in all households round the year. The green leaves, immature and mature bulbs of onion are eaten raw or used in the preparation of food. It is used in soups and sauces for seasoning foods. Pickle is made from young and immature bulbs.

At the micro level, more than 50 percent of the total onion bulb production of the country comes from seven districts of the country namely Hyderabad, Mirpurkhas, Sanghar, Mastung, Kalat, Turbat and Swat. In NWFP, Malakand Division, in general, plays a vital role in onion seed and bulb production. The main onion crop varieties grown in different provinces of the country are Phulkara, Desi Red, Sariab Red and Chiltan-89 and Swat-1 in Sindh, Punjab, Balochistan and NWFP provinces, respectively. However, the productivity potential of onion production is found to be comparatively more in the provinces of NWFP and Balochistan than other two provinces mainly due to favourable agro-ecological conditions. In Balochistan the depletion of water resources due to intensive water mining is a great danger to grow crops which require more water like onion seed and bulb crops and this problem needs to be addressed by the policy-makers before it is too late. This situation also warrants cultivating those crops, which are resource conserving and yielding higher comparative advantage over the lesser beneficial crop enterprises. Onion seed production venture may yield higher profits and also facilitate significantly in reduction of poverty. This issue will be addressed in the present paper through mitigating the severity of poverty by introducing a feasible and lucrative venture of onion seed production in the most specialised ecology of onion seed production like Malakand Division, NWFP, Pakistan. 


\section{Justification and Objectives}

The justification of initiation of this project was manifold. As pointed out earlier that FSC\&RD and PHP had launched a promising intervention with the cooperation of Malakand Division growers to multiply the certified onion seed. This group has contributed about five tones certified onion seed that accounted for less than one percent of the country total demand (800 tones). This intervention claimed to be a big economic motivation for the certified growers in order to reduce their poverty and also saving valuable foreign exchange of the country. Moreover, it created opportunity for the researchers to quantify the real impact of such projects on the mitigation of poverty incidence. The feedback is expected from the results of this project to set right directions for future course of intervention on systematic manners especially to ensure the sustainable returns for the poor growers through on time informing the planners and policy-makers. In view of importance of the quality seed production and significance of the table crop uses as a vegetable, the economic influences of seed multiplication on the certified onion seed growers need to be answered as compared to the conventional crop growers who are not engaged in onion seed production venture in Malakand Division, NWFP. So that farmers can be motivated to produce certified onion seed (presently only six to seven percent used in Pakistan) for facilitating not only multiplication of quality onion seed but also reduction of poverty amongst the growers, in particular, and the on-farm workers, in general, through engaging themselves in the agriculture chores that are labour intensive in onion seed production rather than grain production.

The present study was limited to Malakand Division. Malakand Division consists of Swat, Dir and Buner districts. In the study area Swat-1 variety was grown on the farms of contact farmers with the close technical supervision of Federal Seed Certification and Registration Department (FSC\&RD) as well as Project for Horticultural Promotion (PHP) for multiplication of certified onion seed.

\section{Objectives:}

- Qualify the theoretical concept of rural poverty under the available data set of certified onion seed grower households in Malakand Division;

- to estimate the extent of poverty reduction through income generating activities with special focus of introducing the certified onion seed production venture amongst the selected grower households in the study area; and

- to abridge the gape of poverty through introducing the most promising and economically feasible intervention like maintenance of recommended plant population of certified onion bulb seed, one of the effective and possibly successful agriculture venture considered as a case study in Malakand Division. 


\section{METHODOLOGY AND DATA SOURCES}

\section{Theoretical Foundations of Poverty Measurement}

\section{The Concept of Poverty}

Poverty is a situational syndrome in which under consumption, malnutrition, precarious housing conditions, low educational levels and bad sanitary condition prevailed to leave the victims devoid of basic needs. The concept of poverty has theoretical significance that may seem pedantic when juxtaposed against the dramatic human dimensions of the problem. It is quite clear, however, that the ambiguity underlies in the theory, the concept becomes difficult in any studies due to its preoccupations in ethics and politics. The particular characteristics of the concept that the extreme facet of the problem of the uneven distribution of social goods, and in the political will to devote special efforts for the real life solutions under the available socioeconomic, religious, dialect and cultural values [Altimir (1982)].

\section{The Measurement of Poverty and Limitations}

Given the difficulties inherent in defining poverty as an interactive social situation rather than as a simple juxtaposition of Wants. There is no surprise that operative definitions are restricted to material deprivation. Whereas, the measurements are made in terms of the inadequacy of household resources for arresting determined level of economic welfare at the expense of other dimensions of poverty such as actual psychological deprivation, war fear, terrorist act, specific cultural and ethno-religious patterns and social or occupation manifestations which are not taken, explicitly, into account.

The level of living of a household is the degree to what extent he/she satisfies the needs in accordance with his/her preferences to reach at the level of utility. The household can put into practice or set up for feasible decisions on the allocation of available resources within the setting created by external conditions beyond their control. It would be ideal if the levels of living could be measured in terms of utility or of the degree of satisfaction. It is not the case for real estimation of the poverty line in the present study because of the difficulty in elicitation of aggregate utility function [Altimir (1982); Dasgupta and Pearce (1979)].

Essentially, the given normative nature of the concept of poverty, it has to be measured as standard or levels of living, which may be formulated in either relative or absolute terms. Poverty lines are those normative cut-off lines on the economic welfare dimension of the social pyramid. The representative levels of living below that a household or a person is regarded as poor, and therefore serves to identify the poor. However, the utilisation of arbitrary percentage of the population at the base of the distribution pyramid to represent the poor does not serve to express levels of living, not even in terms of the inequality in those levels. Such utilisation is 
therefore not a measure of poverty itself, despite many claims to the contrary. It is not more than a neurotic manner of referring to poverty.

The conceptual and operative problems surrounding the measurement of poverty are consequently the same as those encountered in the measurement of level of living. Poverty may be measured through the actual access to goods that satisfy needs. The first emphasis could be the direct identification of situation of deprivation with regard to each group of needs. Since it does not call for particular assumption on consumption behaviour. However, the individual preferences passed over in the ranking of different needs for maximisation of his/her utility. On the other hand, the measurement of poverty from the resources standpoint does give this flexibility under the assumption that the household optimises their welfare while the perfect information condition prevail.

The poverty is also a multidimensional concept, which would be applied ideally by establishing normative standards of satisfaction for a group or a resource depending upon the focus chosen for measuring the levels of living. It takes account of different dimensions of welfare. However, it is a cumbersome procedure, requiring explicit handling of existence of situation of partial poverty. Multivariate definition of this type can nevertheless be the most appropriate for the formulation and fallow-up of development strategies.

The count of the number of households below the poverty lines is the most widely used measure of poverty, providing an initial approximate idea of the magnitude of the problem. This measure of the poverty incidence does not take account, however, of either the degree to which the incomes of the poor fall below the poverty line or the inequalities between households at different poverty levels [Altimir (1982)].

\section{Data Sources}

The major source of data for carrying out this study is heavily drawn from the project, "Onion Seed Production and Marketing in Malakand Division: Opportunities and Constraints of Certified Growers". The research project was conducted by the team of social and biological scientists under the supervision of the major author of this paper. The other sources of data used in this paper were from the relevant past studies and published documents.

The universe for this study was Malakand Division, which comprised of three districts namely Swat, Buner, and Dir. Further details about the sampling of the research study is discussed in the report of Saeed and Nasir (2001). Survey was formally conducted during the month of October 2000 and data was collected from a sample of 31 randomly selected contact farmers of Federal Seed Certification and Registration Department (FSC\&RD) from a list of 77 farmers. They were engaged in producing certified onion seed under the technical supervision of FSC\&RD as well as Project for Horticultural Promotion (PHP). The distribution of the sample is given in Table 1. 
Table 1

Distribution of Sample Farmers in Malakand Division

\begin{tabular}{lccc}
\hline Districts & Sample Size & Population & $\begin{array}{c}\text { Sample as Percent } \\
\text { of Population }\end{array}$ \\
\hline Swat & 2 & 3 & 67 \\
Dir & 7 & 15 & 47 \\
Buner & 22 & 59 & 37 \\
All & $\mathbf{3 1}$ & $\mathbf{7 7}$ & $\mathbf{4 0}$ \\
\hline
\end{tabular}

Source: Saeed and Nasir (2001).

In total, thirty-one contact growers were interviewed by using a wellstructured questionnaire having two parts. First part of the questionnaire covered socioeconomic characteristics of the farms and farmers, and the second part entailed the information on cost of production of onion seed and other competing rabi crops, onion bulb and wheat, and kharif season crops, maize and tomato. All the sample farmers were to respond the first part and the selected sample farmers, observed to be resource enumerators among the entire sample of the study, were asked to report the second part of the questionnaire. The sample included 67, 47 and 37 percent of the total contact farmers in Swat, Dir and Buner districts respectively.

\section{Data Analysis}

One observation was dropped from the sample due to incomplete requisite information. The collected data analysed through going into a lot of standardisation to arrive at estimates for each required parameter. In this case, the procedure for computation of cost of production is similar to that used by the Agricultural Prices Commission (APCOM) and adopted in Farm Management Handbook by Ahmed, Hussain and Longmire (1993). This was a unique situation because of hilly terrain and terraced land resources where the crop was cultivated in small fields scattered around in pockets. A special care was practiced to capture true information about the farms, its cultural practices and input/output used for production of different crops. Moreover, each bit of estimated information has to be extrapolated from 'marla' and/or 'kanal' to per acre level. The other detail of enterprise budgets and its profitability analysis alongwith the statistical analysis techniques may be reviewed from the research report of Saeed and Nasir (2001) except the additional analysis carried out regarding improved onion seed crop and income of the households (see in Annexure Tables 1 and 2).

\section{Determination of Poverty Line}

The most commonly used measure of poverty is the "head-count ratio". It measures the proportion of households or populations whose income fall below a 
threshold level termed as poverty line. It is computed based on required calorie and non-calorie for meeting basic food and non-food needs. A poverty measure includes these elements, an indicator of well being or welfare (e.g., per capita calorie intake; per capita expenditure); and a normative threshold representing the well being of an individual or household. It must attain to be above poverty (e.g., a poverty line) and an aggregate measure to assess poverty across population (e.g., head-count ratio). Poverty lines are generally drawn in absolute and/or in relative terms. Relative poverty refers to the position of an individual or household compared with the average income in the country. Absolute poverty refers to the position of an individual or a household in relation to a specific poverty line. This study is based on absolute poverty line.

Two main methods may be employed to compute the poverty line viz., the food energy intake (FEI) method and the cost of basic needs (CBN) method. For the purpose of this study, the poverty line computations were borrowed from the recent study carried out by Qureshi and Arif (1999).

In the present study, the poverty line estimates were worked out based on the computation performed by Qureshi and Arif (1999). In their study, the estimated cost of food consistent with a calorie intake of 2550 per adult equivalent per day was carried out for rural areas of Pakistan. These calories are considered to be a balanced diet comprising of food items typically consumed in Pakistan by the rural community and ensuring a certain level of calorie and protein intake that is valued using representative prices. The expenditure on non-basic food needs is then taken into account to determine the income at which the minimum balanced diet can be ensured. This information is then applied to the distribution of population for determining per capita income in respect of each target group to estimate the population whose income falls below the poverty line. The information of 1998-99 was updated for 1999-2000 by using the corresponding percent interest of food inflation rate and sensitive price indicators to estimate the food poverty line and basic need poverty line respectively (Table 2).

Table 2

Estimated Poverty Lines Based on Calorie Intake and Basic Need Approaches for Malakand Division's Rural Regions

\begin{tabular}{lccc}
\hline & $\begin{array}{c}\text { Inflation } \\
\text { 1998-99 HIES } \\
\text { Poverty Lines }\end{array}$ & $\begin{array}{c}\text { Rate } \\
\text { (\%) }\end{array}$ & $\begin{array}{c}\text { 1999-2000 Estimate } \\
\text { (Rs Per Capita) }\end{array}$ \\
\hline Food Poverty Line & 353.73 & 2.20 & 361.51 \\
Basic Need Poverty Line & 672.50 & 1.83 & 684.81 \\
\hline Source: Qureshi and Arif (1999) and Pakistan (2001-2002). \\
Note: Food Inflation rate used for estimating Food Poverty Line and Sensitive Price Indicator for \\
$\quad$ determining Basic Need Poverty Line.
\end{tabular}


It is not possible to construct an absolute definition of poverty because of its difficulty in isolation from the social context within which the needs are created and satisfied. The determination of poverty line is always under lot of critics. Despite all these, the use of household's income is highly acceptable measure to assess a poverty line. Generally, two main questions have been in vogue when measuring incidence of poverty. Firstly, what is the percentage of the population that falls under poverty? It is termed as the 'extent' of poverty. Secondly, what is the 'depth' of the degree of poverty? In other words, how far below the poverty line who were considered to be poor? The discussion of the poverty line and its determination is discussed in detail and can be reviewed from the research report of Davidson; Ahmad and Chaudhry (1996). The computation formulae for these two measures are discussed as follow:

\section{Measuring the Extent of Poverty (The Head Count Ratio)}

The degree of poverty may be measured by employing this formula;

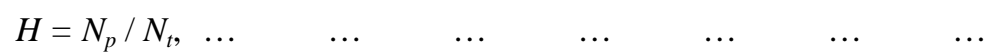

Where: ' $H$ ' is the proportion of households considered to be in poverty;

' $N_{p}$ ' is the number of households in poverty; and

' $N_{t}$ ' is the total number of households.

In Equation (1.1) ' $N_{p}$ ' term can be estimated by applying the following formula for each household $(\mathrm{Ni})$ with respect to all households $(i=1+2+3 \ldots p)$, summing to equal $N_{p}$ :

$$
\mathrm{Ni}=\mathrm{Yi}+\mathrm{Ai}<\mathrm{PL}+\mathrm{Bi}, \quad \ldots \quad \ldots \quad \ldots \quad \ldots \quad \ldots \quad \ldots
$$

Where ' $Y i$ ' is the net income of a given economic unit (household) $i$; 'Ai' is any adjustment that may need to be made to the level of household's income e.g., net sale and purchases of livestock and net crop income per year (less all variable and fixed costs);

' $P L$ ' is yet to be defined poverty Line; and

' $B i$ ' is any adjustment that may need to be made to the concept of poverty to update for particular period, such as the food and non-food household needs updated through employing the corresponding inflation rates.

It is worth noting that each member of a household shares equal income amongst all members. Therefore, it is not possible to extend the analysis of the effects of poverty on selected sub-groups beyond an assessment of its extent. Similar is the case for the assessment of the depth of poverty across sub-groups because the level of income in each group is not known. 


\section{Measuring the Depth of Poverty (the Poverty Gap Index)}

The poverty gap index is based on the aggregate shortfall of income of all the poor. The poverty gap index associated with household income unit ' $i$ ' is given by;

$$
\begin{array}{lllllll}
G i=P L-Y i & \ldots & \ldots & \ldots & \ldots & \ldots & \ldots
\end{array}
$$

Where: ' $G i$ ' is the income shortfall of household ' $i$ '; and

All other variables are as defined above.

Many analysts including Sen (1976) considered that the poverty gap index to be of limited use as it does not reflect the severity of the poverty problem in terms of the number of people who suffer [Davidson, Ahmad and Chaudhry (1996)]. However, the use of both the poverty gap measure and the head count ratio may overcome this deficiency. Moreover, the computation of reliable poverty index requires a huge data set, but in case of present paper the data is very limited. Thus, estimation of poverty index was not carried out.

\section{Determination of Farm Household Income}

Let us define types of household before proceeding with the discussion of household income determination, such as:

A single-person household "who makes provision for his own food and other essentials of living without combining with any other person and has no usual place of residence elsewhere".

A multi-person household "it is a group of two or more persons who make some common provision for food or other essentials of living and have no usual place of residence elsewhere. The persons constituting the group may pool their incomes and have a common budget to a greater or lesser extent; they may be related or unrelated or a combination of both. The general criterion to be used in identifying the members of a multi-person household relates to whether they live and eat together and have no usual place of residence elsewhere” [FBS (1999), p. 1.]

In a rural environment of Pakistan, it is generally believed that all households will be made up of extended family groups, and no other types of household existed. However, in reporting information on households, it is important to obtain the demographic composition of each economic unit (household) for understanding its strength (size). It was observed in the present study as well as in other studies that the size of the family differs between its income earning and expenditure functions. In some families, the male labour force was working overseas and sending back home remittances to supplement the income of their families.

The farm income of an economic unit (household) received from number of sources in the study area. The major income sources per year were crop, livestock, wages/salaries and remittances. The actual household income from business was not included in the study because of poor data quality and minimal business activity 
found in the study area. Furthermore, this deficiency compensated by including the wages and salaries of the full and part time male and female labour force available at farm and off-farm belonging to each farm family of the surveyed households. The wage rate of the on-farm/off-farm full time male workers was computed for the first worker at the rate of Rs 3600 per month and else worth Rs 3000 per month against eight months in a year. Whereas the same wage rates were imputed for on-farm/offfarm part time male workers for three months in a year. These calculations were made on the basis of 67 and 25 percent employment rate per annum for both full time and part time male workers (on-farm/off-farm), respectively. Similarly, the family female workers' wages were imputed counting the opportunity cost wage rate of Rs 1800 per month for the first worker and else wage rate of Rs 1500 per month against eight and two months in a year for full time and part time (on-farm/off-farm) employment respectively. The female employment engagement (on-farm/off-farm) was worked out to be at the rate of 67 and 17 percent per annum for full time and part time basis, respectively.

The net income of rabi (wheat, onion bulb and onion seed) and kharif (maize and tomato) crops borrowed from the study carried out by Saeed and Nasir (2001). This income was a proxy while computing the crop income of the households. The other sources of the income were directly utilised from the survey information like remittances and net of animal sales and purchases in addition to wages and salaries, as discussed earlier. For the purpose of accomplishing this study, three income levels were computed with scenarios of adopting new venture of high value crop. For example, in scenario one, income without onion seed production but replacing the same area with onion bulb crop production, scenario two income from seed production, scenario three income from seed production with improved practices through maintaining the recommended plant population. The cropping intensity was assumed same as they practiced during the survey year, 2000. The farm crop area allocation was used same which came out in the study survey including the onion seed area. The detail of computations is presented in Annexure tables.

The income measurement technique of an economic unit used in the present study was based on the evidence of the previous studies as well as perceived from the observations and experiences of the authors of this paper [Davidson, Ahmad and Chaudhry (1996) and Saeed and Nasir (2001)].

\section{RESULTS AND DISCUSSION}

The problem of hunger and poverty is global in nature. It involves the judicious strategies of income distribution through empowering the consumers in number of ways but mainly through increasing the purchasing power of a household by enhanced disposable income. This is the case that has been presented in the current paper by adapting a successful case study of certified onion seed production venture, launched by FSC\&RD in collaboration with PHP on the farms of 
cooperating certified contact growers. In this paper, the incidence and nature of poverty is determined amongst the sample certified onion seed truly production households in three districts of Malakand Division, NWFP. This region is not representing either the NWFP province of Pakistan. Therefore extrapolation of this paper's research results at national level is not possible, and the results are more specific to the sample group in the study region.

The background of the successful case study is presented in terms of three levels of income viz.:

(i) income without onion seed (assumed to be replaced with onion bulb crop) equal Rs 12625.22 per acre;

(ii) income with onion seed (actually practiced by the sample farmers) equal Rs 115691.32 per acre; and

(iii) income with improved practices (proposed recommended intervention through adopting proper onion bulb size with desired plant density) equal Rs 167515.88 per acre.

The details of household income determination were discussed in methodology section. The levels of technology for the production of onion seed and bulb crops is elaborated for the purpose of income computation in research report of Saeed and Nasir (2001) and partly in Annexure Tables 1 and 2. The households' income jumped from lower to higher bracket by introducing new venture of onion seed production where they used to plant onion bulb crop. This venture, on average, increased the net income by Rs 103066.10 per acre of the farmers who cooperated with FSC\&RD to plant certified onion seed crop (Swat-1 variety) rather than onion bulb crop in the study area. As discussed in earlier sections, the sample farmers of this study were the contact growers of certified onion seed with the technical supervision of FSC\&RD and PHP, NWFP. Thus, these farmers are special who might not be representing the true picture of poor to non-poor ratio. Moreover, all these farmers are owner or owner-cum-tenant but the representation of landless is totally missing who are more likely to be the major victim of poverty in Pakistan [Khan (1987)].

In the present case study, the potential of quality onion seed production may be explored farther by introducing the improved intervention of maintaining recommended bulb size and higher plant density with adjusting all other inputs almost at same level as have been applied by the onion seed producer households under the technical supervision of FSC\&RD, as well as strengthening of the local community based organisations for sharing input-output marketing and financial management. As a result, the contact households income could possibility be increased to the tone of Rs 51825 per acre, over and above the present production level, through adopting the proposed improved onion seed production practices. The story of certified onion seed growers belonging to Malakand Division is being used as a case study for assessing the extent and nature of poverty in the present paper. 
The head-count ratio and poverty gap techniques were used to measure the incidence and depth of poverty in the following section. Lastly, the characteristics of poor vs. non-poor households are also discussed for the study area.

\section{The Extent of Poverty}

The head-count ratio reveals the proportion of the households who are poor and fall below the poverty line. The extent of poverty is assessed not only in terms of number and percent of households but also in sub groups of male, female and children folks of each household in the sample study area. These results are portrayed in Table 3.

Of the 30 sample households, eight were found to fall below food poverty line based on the assessment made for the sample household whose income source come from the income scenario one (onion bulb crop production-without onion seed production). These figures represent 27 percent of all the households surveyed. In terms of the higher poverty line based on basic need method, 19 households were found to fall below the food poverty line based on the derived food poverty line as elaborated in Table 2. These figures represent nearly 63 percent of the households who fall below the poverty line.

Table 3

Proportion of Poor Households in Rural Areas of Malakand Division, 1999-2000

\begin{tabular}{|c|c|c|c|c|c|c|}
\hline \multirow[b]{2}{*}{ Items } & \multicolumn{3}{|c|}{ Food Poverty Line } & \multicolumn{3}{|c|}{ Poverty Based on Basic Needs Methods } \\
\hline & $\begin{array}{c}\text { Income } \\
\text { with- } \\
\text { out Onion } \\
\text { seed }\left(\mathrm{Y}_{1}\right) \\
\end{array}$ & $\begin{array}{c}\text { Income } \\
\text { with Onion } \\
\text { Seed } \\
\left(\mathrm{Y}_{2}\right) \\
\end{array}$ & $\begin{array}{c}\text { Income of } \\
\text { Improved } \\
\text { Practices } \\
\left(\mathrm{Y}_{3}\right) \\
\end{array}$ & $\begin{array}{c}\text { Income } \\
\text { with- } \\
\text { out Onion } \\
\text { seed }\left(\mathrm{Y}_{1}\right) \\
\end{array}$ & $\begin{array}{c}\text { Income } \\
\text { with Onion } \\
\text { Seed } \\
\left(\mathrm{Y}_{2}\right) \\
\end{array}$ & $\begin{array}{c}\text { Income of } \\
\text { Improved } \\
\text { Practices } \\
\left(\mathrm{Y}_{3}\right)\end{array}$ \\
\hline \multicolumn{7}{|l|}{ Households } \\
\hline - Numbers & 8 & 2 & 1 & 19 & 7 & 6 \\
\hline - Percentage & 26.7 & 6.7 & 3.3 & 63.3 & 23.3 & 20.0 \\
\hline \multicolumn{7}{|l|}{ Male } \\
\hline - Numbers & 3 & 1 & 1 & 4 & 1 & 1 \\
\hline - Percentage & 10.0 & 3.3 & 3.3 & 13.3 & 3.3 & 3.3 \\
\hline \multicolumn{7}{|l|}{ Female } \\
\hline - Numbers & 3 & 1 & 1 & 3 & 1 & 1 \\
\hline - Percentage & 10.0 & 3.3 & 3.3 & 10.0 & 3.3 & 3.3 \\
\hline \multicolumn{7}{|l|}{ Children } \\
\hline - Numbers & 3 & 0 & 0 & 9 & 2 & 1 \\
\hline - Percentage & 10.0 & 0 & 0 & 30.0 & 6.7 & 3.3 \\
\hline
\end{tabular}


The number of households reduced from eight to two who fall below food poverty line when the households switched from income scenario one to Two (income of onion seed growers - the present farmers status). Similarly, the households reduced from 19 to 7 who fall below the total poverty line through adopting the onion seed production venture based on the poverty line assessed on basic need method. This figure represents the households who fall below the basic need poverty line where the incidence of poverty reduced to 23 percent from 63 percent. The households who fall below food poverty line came out to be one (3 percent) against six (20 percent) when the income scenario three adopted (income of improved onion seed producers) in respect of food and basic need poverty lines respectively. According to the results given in Table 3, the incidence of poverty influenced relatively more on children folks of surveyed households specially based on the basic need method approach. The scenario of income level one is influencing mildly when switching to income level two or three in case of food poverty and basic need poverty lines.

\section{The Depth of Poverty}

The depth of poverty is measured using the poverty gape index, which interprets the aggregate short fall in incomes of those who fall below determined food and basic need poverty lines. The depth of poverty is derived from incomes if it can only be appropriately applied to income units such as households and not to any sub groups. Therefore, in this study the depth of poverty is not applied for any sub group of households. The depth of poverty results is presented in Table 4. In this table, the poverty line of poor vs. non-poor households is presented. For example, in case of food poverty line the households who fall below food poverty line, their average income per month per capita came out to be Rs 177.33 under income scenario one. Whereas, the average per month per capita short fall came out to be Rs

Table 4

The Depth of Poverty

\begin{tabular}{|c|c|c|c|c|}
\hline \multirow{2}{*}{$\frac{\text { Poverty Line }}{\text { Food Poverty }}$} & \multicolumn{2}{|c|}{$\begin{array}{c}\text { Poor Households } \\
\text { Non-poor Household } \\
\text { (Rs Per Month per } \\
\text { Capita) }\end{array}$} & \multicolumn{2}{|c|}{$\begin{array}{l}\text { Poor Households } \\
\text { Non-poor Households } \\
\text { (Percent) }\end{array}$} \\
\hline & & & & \\
\hline - Income without Onion Seed $\left(\mathrm{Y}_{1}\right)$ & 177.33 & 893.75 & 26.7 & 73.3 \\
\hline - Income with Onion Seed $\left(\mathrm{Y}_{2}\right)$ & 163.10 & 1292.98 & 6.7 & 93.3 \\
\hline - Income with Improved Onion Seed Practices $\left(\mathrm{Y}_{3}\right)$ & 20.54 & 1526.80 & 3.3 & 96.7 \\
\hline \multicolumn{5}{|l|}{ Poverty Based on Basic Need Method } \\
\hline - Income without Onion Seed $\left(\mathrm{Y}_{1}\right)$ & 379.87 & 1260.32 & 63.3 & 36.7 \\
\hline - Income with Onion Seed $\left(\mathrm{Y}_{2}\right)$ & 435.62 & 1455.67 & 23.3 & 76.7 \\
\hline - Income with Improved Onion Seed Practices $\left(\mathrm{Y}_{3}\right)$ & 472.88 & 1727.52 & 20.0 & 80.0 \\
\hline
\end{tabular}


163.10 and Rs 20.54 for the income scenario two and three, respectively. Similarly, the estimated per month per capita shortfall of the income came out to be Rs 380, Rs 436 and Rs 473 under basic food need for the income scenario of one, two and three levels, respectively. As discussed earlier, the proportion of households who fell below the food poverty line reduced from 27 percent to 3 percent as they switched from onion bulb crop production to improved onion seed practices. Similarly, the households who fall below the poverty line reduced from 63 to 20 percent as if they are adopting the improved onion seed production venture.

\section{The Characteristics of Sample Households}

The detail of the characteristics of sample households is presented in Table 5. The characteristics of the sample households include average land size, owned and operational. The poor households are relatively owning and operating lesser acres than the non-poor households. Similarly, the poor households are maintaining less animal units than the non-poor households. The number of children is almost twice with the poor households than the non-poor households. The housing condition of poor households is bad than the non-poor households in terms of 'kacha' vs. 'pucca'

Table 5

\section{Characteristics of Sample Households}

\begin{tabular}{|c|c|c|c|c|}
\hline Item & Units & All Households & $\begin{array}{c}\text { Poor } \\
\text { Households }\end{array}$ & $\begin{array}{l}\text { Non-poor } \\
\text { Household }\end{array}$ \\
\hline Number of Households & No. & 30 & 6 & 24 \\
\hline Average Land Size Own (Total) & Acres & 5.94 & 4.5 & 7.1 \\
\hline Average Land Size (Operational) & Acres & 5.27 & 4.5 & 7.2 \\
\hline \multicolumn{5}{|l|}{ Livestock Inventory } \\
\hline$-\mathrm{L} / \mathrm{S}$ & No. & 3.7 & 3.2 & 3.6 \\
\hline Size of Family & No. & 9.73 & 10.50 & 9.54 \\
\hline - Males & No. & 2.96 & 2.63 & 2.44 \\
\hline - Females & No. & 2.87 & 2.42 & 3.00 \\
\hline - Children & No. & 4.16 & 5.10 & 2.55 \\
\hline \multicolumn{5}{|l|}{ Other Standards } \\
\hline - Dwelling Status & $\%$ & $\begin{array}{l}\text { Own = 83.3 } \\
\text { Rented =16.7 }\end{array}$ & $\begin{array}{l}\text { Own = 88.9 } \\
\text { Rented =11.1 }\end{array}$ & $\begin{array}{l}\text { Own }=87.0 \\
\text { Rented }=13.0\end{array}$ \\
\hline - Housing Condition & $\%$ & $\begin{array}{l}\text { Kacha }=67.7 \\
\text { Pucca }=32.3\end{array}$ & $\begin{array}{l}\text { Kacha }=83.3 \\
\text { Pucca }=16.9\end{array}$ & $\begin{array}{l}\text { Kacha }=62.3 \\
\text { Pucca }=37.5\end{array}$ \\
\hline - Electricity Supply & $\%$ & $\begin{array}{l}\text { Yes }=64.5 \\
\text { No }=35.5\end{array}$ & $\begin{array}{l}\text { Yes }=100.0 \\
\text { No }=0.0\end{array}$ & $\begin{array}{l}\text { Yes }=58.3 \\
\text { No }=41.7\end{array}$ \\
\hline - Road Access (Distance) & KM & 1.54 & 0.7 & 1.3 \\
\hline - Drinking Water Availability & $\%$ & $\begin{array}{l}\text { Yes }=90.3 \\
\text { No }=9.7\end{array}$ & $\begin{array}{l}\text { Yes }=100.0 \\
\text { No }=0.0\end{array}$ & $\begin{array}{l}\text { Yes }=87.5 \\
\text { No }=12.5\end{array}$ \\
\hline - Medical Facility & $\%$ & $\begin{array}{l}\text { Yes }=90.3 \\
\text { No }=9.7\end{array}$ & $\begin{array}{l}\text { Yes }=66.7 \\
\text { No }=33.3\end{array}$ & $\begin{array}{l}\text { Yes }=95.8 \\
\text { No }=4.2\end{array}$ \\
\hline
\end{tabular}

Source: Khan, et al. (1999).

Note: The livestock equalling units are computed based on the units like; Bufalow milk $=1.5$, BuffalowBuffalow adult male $=1.2$ young $=0.6$, Cow $=1$, Donkey $=0.5$, Sheep and Goat $=0.25$ 
houses. Similarly the medical facilities are not favouring the poor households than the non-poor households. All these results are verified from the response of the households from the survey areas as presented in Annexure Table 3.

The important socioeconomic indicators including religious ceremonies, cultural meeting, schooling, housing, agriculture land purchases, improved input use, farm mechanisation and investment in land improvement were proved to be a change in their expenditure behaviour consequent upon their income level elevated from the lower to higher levels through adopting the onion seed production venture. One of the most important elements with regard to socioeconomic impact was pay back a previous loan taken by the onion seed growers due to enhanced income by introducing onion seed production venture at their farms. A major portion of their savings also went for looking after their social needs like marriages, cultural ceremonies and health care of their families. The other important changed status of the increased income households may be observed from Annexure Table 3.

\section{SUMMARY AND CONCLUSION}

Poverty is a natural phenomenon of each community but roughly one-third of the total population of the developing countries has been documented in the literature. About 35 percent of the rural inhabitants of Pakistan live in poverty. The income distribution has been worsened in the rural areas as against the urban areas where, it has marginally improved during the period from 1979 to 1997. It is a recognised fact that agricultural growth is one of the priority issues coupled with poverty reduction in Pakistan. In line, the government of Pakistan has adopted some measures of poverty reduction on priority basis through addressing effective policy measures and technology led development.

In the present paper, the scenario of a successful case study was presented on onion seed production venture to address the twin problem of poverty and low rate of agricultural growth. The study was carried out by a multi-disciplinary team of social and biological professionals from PARC, Federal Seed Certification and Registration Department (FSC\&RD) and Project for Horticultural Promotion (PHP), NWFP. The study registered a significant contribution towards production of certified quality onion seed, and as a result, it increased the net income of the growers that would be catalytic for the reduction of their poverty. Furthermore, it will be helpful in saving the valuable foreign exchange which has already been spending on the import of quality onion seed, and increasing the employment opportunities of the owner farmers and landless labourers through engaging in the labour intensive activities.

The results presented in this paper covered the Malakand Division comprising of Swat, Dir and Buner Districts. Swat-1 variety of onion crop represented the onion seed production venture on the farms of contact farmers was initiated with the close technical supervision of Federal Seed Certification and Registration Department and project for Horticultural Promotion (PHP). In the case study, a sample of 31 contact 
onion seed growers was interviewed by using a well-structured questionnaire. The size of the sample is comprised of 67, 47 and 37 percent of the total contact farmers in Swat, Dir and Buner districts, respectively.

The main purpose of this research project presented in the present paper is to estimate the extent of poverty reduction through using a case of successful project in respect of income generating activities of certified onion seed production venture by the contract grower households.

A standard methodology of poverty determination including 'head-count ratio' is utilised based on absolute poverty line. The salient findings of the research project presented in this paper are as follow:

The farm income of an economic unit (household) have been generated from number of sources including crop and livestock products, wages/salaries and remittances; and income from business is not included for maintaining accuracy because of non-availability of reliable data.

The net income of rabi (i.e., wheat, onion bulb and onion seed) and kharif crops (i.e., maize and tomato) borrowed from the recent study that carried out by Saeed and Nasir (2001). The other sources of income include remittances, net of animal sales and purchases, wages and salaries, were taken from survey information.

Three income levels were computed with the given technology scenarios:

(1) No Technology Intervention: Income without onion seed production but, replaced the same area with onion bulb crop that computed to the tune of Rs 12625 per acre.

(2) Technology Intervention (farmers' own practices for all inputs except certified seed): Income from certified onion seed production came out to be Rs 115691 per acre.

(3) Technology Intervention (recommended plant population): Income from seed production with improved and recommended practices through maintaining plant population (seed rate), computed to the tune of Rs 167516 per acre.

The scope of this paper is only limited to owner and owner-cum tenant farming community but land less rural population is not included.

The households average net income increased by Rs 103066 per acre who cooperated with FSC\&RD and declared a contact grower through planting certified onion seed crop for quality seed production in place of onion bulb crop production. Similarly, the net income of the contact growers can be increased further to the tune of Rs 51825 if the improved practices of onion seed production would be adopted via maintaining only the recommended plant population.

The sustainability of quality onion seed production can only be maintained if the continuity of technical back stopping of FSC\&RD and PHP stays along with the support of marketing facilities for processing of inputs and outputs through 
strengthening of existing community based organisations. Moreover, micro credit financing facility need to be extended on the patterns of development programmes launched in mountainous regions under the supervision of AKRSP, SRSC and BRSP [Mohmand (1999)]. A special consideration warranted in the Malakand Division to develop micro-credit programmes that should be based on interest free loaning system in order to attract and satisfy the credit needs of the farming community.

The poverty determination techniques used like, head-count ratio and poverty gap to measure the incidence and depth of poverty. As per three income levels with reference to different technology scenarios, the analysis presented in the paper is classified into poor versus non-poor households. According to income scenario one (onion bulb crop production termed as without onion seed production), 27 percent of the households fell below poverty line when assessed based on food poverty as against 63 percent fell below poverty line when assessed based on basic need method. The poverty incidence reduced from 63 percent to 23 percent when assessed based on total poverty line (basic need method) under the household's income scenario of two (i.e., certified onion seed production-farmers' own practices). The incidence of total poverty reduced further from 23 percent to 20 percent when assessed under income scenario three (onion seed production with improved technology-maintained recommended plant population). The overall poverty incidence is relatively more severe on children folks than that of male and female subgroups of the surveyed households in the Malakand Division.

This is an alarming situation where the children folks demand special attention to take care of their food, fiber and shelter but also the other important social basic need indicators are socio-cultural and religious. It is evident from another study conducted by Saeed and Nasir (2001), where the enhanced income is being spent on quality education of children and repayment of past loans taken by the sample households.

The depth of poverty illustrates the average income short fall to the extent by Rs 177, Rs 163 and Rs 21 per month per capita when assessed under food poverty line method for the onion bulb crop, onion seed and improved practices of onion seed production, respectively. It is other way round when assessed under basic need method but with lesser disparity. This implies that the farmers who received higher income from the onion seed production venture were in lesser short fall of food poverty line than basic need poverty line. Furthermore, the households who are involved in production of onion seed are investing more on basic need than onion bulb crop. These findings are also supporting to the status of food supply in the region, which is net importing of major food items. 
Annexure Table 1

Annexures

Cost of Production of Improved Onion Seed Crop Practices in Malakand Division

\begin{tabular}{|c|c|c|c|c|}
\hline Sr.No. & Operation/Inputs & $\begin{array}{l}\text { No./ } \\
\text { Qty }\end{array}$ & $\begin{array}{c}\text { Rate per } \\
\text { Unit }\end{array}$ & $\begin{array}{l}\text { Cost per } \\
\text { Acre }\end{array}$ \\
\hline & Costs & & & \\
\hline 1. & Preparatory tillage and land (nos. + tractor hours) preparation & 2.82 & 452.29 & 1275.46 \\
\hline 2. & Bund/ridge making (m.days) & 7.11 & 100 & 711 \\
\hline 3. & Bulb seed (kgs) & 2050 & 9.94 & 20377.00 \\
\hline 4. & Labour for sowing bulb (m.days) & 31.76 & 100 & 3176 \\
\hline \multirow[t]{3}{*}{5.} & Farm Yard Manure & & & \\
\hline & (i)Manure and transportation & & & 2472.22 \\
\hline & (ii) Spreading (m.days) & 2.97 & 100 & 297 \\
\hline \multirow[t]{6}{*}{6.} & Chemical fertilisers: & & & \\
\hline & (i) DAP & 2 & 684.22 & 1368.44 \\
\hline & (ii) Urea & 1.5 & 347.27 & 520.91 \\
\hline & (iii) Potash & 1 & 616 & 616 \\
\hline & (iv) Transportation & 4.5 & 9.17 & 41.27 \\
\hline & (v) Labour for application (m.days) & 2.51 & 100 & 251 \\
\hline 7. & Plant protection (sprays) & & & 2208 \\
\hline 8. & Labour for application (m.days) & 2 & 100 & 200 \\
\hline 9. & Weeding/hoeing/earthing (m.days) & 24 & 100 & 2400 \\
\hline \multirow[t]{5}{*}{10.} & Irrigation: & & & \\
\hline & (i) Canal water rate & & & 0 \\
\hline & (ii) Supplementary tubewell & 1.44 & 69.33 & 99.84 \\
\hline & (iii) Labour for irrigation (m.days) & 11.61 & 100 & 1161 \\
\hline & (iv) Water course clearing (m.days) & 2.15 & 100 & 215 \\
\hline 11. & Cutting of tops (m.days) & 25 & 100 & 2500 \\
\hline 12. & Threshing (m.days) & 20 & 100 & 2000 \\
\hline 13. & Winnowing and cleaning(m.days) & 24 & 100 & 2400 \\
\hline 14. & Packing (m.days) & 1.5 & 100 & 150 \\
\hline 15. & Mark-up on investment @14.0\% per annum ( ) for 8 months & & & 4147.74 \\
\hline 16. & Land rent for 8 months & 8 & 991.67 & 7933.33 \\
\hline 17. & Management charges (8 months) & & 358.00 & 238.67 \\
\hline 18. & Land revenue, etc. & & & 10.00 \\
\hline \multirow[t]{7}{*}{19.} & Post harvest cost for marketing (Rs) & & & \\
\hline & (a) Packing Labour & 325 & 0.69 & 224.25 \\
\hline & (b) Packing Material & 325 & 12 & 3900 \\
\hline & (c) Tag & 325 & 0.62 & 201.50 \\
\hline & (d) Carton (1 cartoon = $8 \mathrm{Kg}$ ) & 40.63 & 20 & 812.50 \\
\hline & (e) Sewing & 325 & 0.77 & 250.25 \\
\hline & (f) Transportation and loading (field to store) & 325 & 1 & 325 \\
\hline 20. & A. Yield $\quad$ (kgs) & 325 & 707.69 & 229999.25 \\
\hline 21. & B. Total cost per acre & & & 62483.37 \\
\hline 22. & Variable cost per acre (Rs) & & & 54301.37 \\
\hline 23. & Fixed Cost per acre (Rs) & & & 8182.00 \\
\hline 24. & Gross margin per acre (Rs) & & & 175697.88 \\
\hline 25. & Net Income per Acre (A-B)—(Rs) & & & 167515.88 \\
\hline
\end{tabular}


Annexure Table 2

Total Income of Household from Various Sources, Malakand Division

\begin{tabular}{|c|c|c|c|c|c|c|c|c|c|}
\hline $\begin{array}{l}\text { Sr. } \\
\text { No. }\end{array}$ & $\begin{array}{l}\text { Income } \\
\text { with } \\
\text { Onion } \\
\text { Bulb }\end{array}$ & $\begin{array}{l}\text { Income } \\
\text { with } \\
\text { Onion } \\
\text { Seed }\end{array}$ & $\begin{array}{l}\text { Improved } \\
\text { Income }\end{array}$ & $\begin{array}{c}\text { Net } \\
\text { Live- } \\
\text { stock } \\
\text { Income }\end{array}$ & $\begin{array}{c}\text { Remitt- } \\
\text { ances }\end{array}$ & $\begin{array}{c}\text { Total } \\
\text { Wages }\end{array}$ & $\begin{array}{c}\text { Total } \\
\text { Income } \\
\text { with } \\
\text { Onion } \\
\text { Bulb }\end{array}$ & $\begin{array}{c}\text { Total } \\
\text { Income } \\
\text { with } \\
\text { Onion } \\
\text { Seed }\end{array}$ & $\begin{array}{c}\text { Total } \\
\text { Improved } \\
\text { Income }\end{array}$ \\
\hline 1. & 17737.04 & 69270.09 & 95182.37 & 0 & 0 & 31800 & 49537.04 & 101070.1 & 126982.4 \\
\hline 2. & 12625.22 & 115691.3 & 167515.9 & 0 & 0 & 36000 & 48625.22 & 151691.3 & 203515.9 \\
\hline 3. & 19920.64 & 58570.43 & 78004.64 & 0 & 0 & 28800 & 48720.64 & 87370.43 & 106804.6 \\
\hline 4. & -1284.89 & -1284.89 & -1284.89 & 0 & 0 & 60000 & 58715.11 & 58715.11 & 58715.11 \\
\hline 5. & -1284.89 & -1284.89 & -1284.89 & 0 & 0 & 96000 & 94715.11 & 94715.11 & 94715.11 \\
\hline 6. & -7486.66 & 18279.87 & 31236.01 & 0 & 30000 & 72000 & 94513.35 & 120279.9 & 133236 \\
\hline 7. & -4242.54 & -4242.54 & -4242.54 & 0 & 0 & 7200 & 2957.46 & 2957.46 & 2957.46 \\
\hline 8. & 2346.1 & 53879.15 & 79791.43 & 2000 & 0 & 34800 & 39146.1 & 90679.15 & 116591.4 \\
\hline 9. & 3001.06 & 3001.06 & 3001.06 & 0 & 0 & 69600 & 72601.06 & 72601.06 & 72601.06 \\
\hline 10. & 7756.4 & 33522.92 & 46479.06 & 0 & 19200 & 28800 & 55756.4 & 81522.92 & 94479.06 \\
\hline 11. & -5431.18 & 97634.93 & 149459.5 & 0 & 0 & 15000 & 9568.82 & 112634.9 & 164459.5 \\
\hline 12. & 18815.97 & 70349.02 & 96261.3 & 5000 & 0 & 82000 & 105816 & 157349 & 183261.3 \\
\hline 13. & -2456.38 & 10426.89 & 16904.96 & -5000 & 100000 & 1524000 & 1616544 & 1629427 & 1635905 \\
\hline 14. & -13591.7 & 50824.64 & 83214.99 & -1000 & 0 & 100800 & 86208.33 & 150624.6 & 183015 \\
\hline 15. & 39408.04 & 142474.1 & 194298.7 & -5000 & 0 & 100800 & 135208 & 238274.1 & 290098.7 \\
\hline 16. & 724.22 & 4589.19 & 6532.62 & 1200 & 200000 & 34800 & 236724.2 & 240589.2 & 242532.6 \\
\hline 17. & 11047.07 & 49696.86 & 69131.07 & 0 & 0 & 52800 & 63847.07 & 102496.9 & 121931.1 \\
\hline 18. & 21064.01 & 53220.64 & 69389.9 & -5000 & 0 & 148800 & 164864 & 197020.6 & 213189.9 \\
\hline 19. & 12625.22 & 64158.27 & 90070.55 & 9000 & 0 & 52800 & 74425.22 & 125958.3 & 151870.6 \\
\hline 20. & 22219.32 & 151051.9 & 215832.6 & 0 & 0 & 54000 & 76219.32 & 205051.9 & 269832.6 \\
\hline 21. & 21594.42 & 227726.6 & 331375.7 & 36100 & 0 & 13200 & 70894.42 & 277026.6 & 380675.7 \\
\hline 22. & -1086.24 & 24680.29 & 37636.43 & 0 & 0 & 12000 & 10913.77 & 36680.29 & 49636.43 \\
\hline 23. & 4191.34 & 55724.39 & 81636.67 & 0 & 0 & 28800 & 32991.34 & 84524.39 & 110436.7 \\
\hline 24. & 336.67 & 51869.72 & 77782 & -5000 & 0 & 28800 & 24136.67 & 75669.72 & 101582 \\
\hline 25. & -51.2 & 38598.59 & 58032.8 & 0 & 0 & 6000 & 5948.8 & 44598.59 & 64032.8 \\
\hline 26. & -18.66 & 63882.32 & 96013.55 & 0 & 0 & 28800 & 28781.34 & 92682.32 & 124813.5 \\
\hline 27. & 1009.43 & 52542.49 & 78454.77 & 0 & 0 & 28800 & 29809.44 & 81342.49 & 107254.8 \\
\hline 28. & 2906.45 & 54439.5 & 80351.78 & -7900 & 0 & 196800 & 191806.5 & 243339.5 & 269251.8 \\
\hline 29. & 2414.53 & 15297.8 & 21775.87 & 0 & 0 & 100800 & 103214.5 & 116097.8 & 122575.9 \\
\hline 30. & 4861.5 & 56394.55 & 82306.83 & 0 & 0 & 13200 & 18061.5 & 69594.55 & 95506.83 \\
\hline
\end{tabular}


Annexure Table 3

Socioeconomic Impact of the Onion Seed Production Venture on the Farming Community

\begin{tabular}{|c|c|c|c|c|c|c|}
\hline \multirow{2}{*}{$\begin{array}{l}\text { S. } \\
\text { No. }\end{array}$} & \multirow[b]{2}{*}{ Socio-economic Indicators } & \multicolumn{2}{|c|}{ No Change } & \multicolumn{2}{|c|}{ Changed Status } & \multirow[b]{2}{*}{ Remarks } \\
\hline & & No & $\%$ & No & $\%$ & \\
\hline 1. & Religious Ceremonies & 26 & 83.9 & 5 & 16.1 & \multirow{5}{*}{$\begin{array}{l}\text { 3rd } \\
\text { ranked }\end{array}$} \\
\hline \multirow[t]{4}{*}{2.} & Cultural/Meetings & 24 & 77.4 & 7 & 22.6 & \\
\hline & (i) Marriage & 29 & 93.5 & 2 & 6.5 & \\
\hline & (ii) Food Stuff & 27 & 87.1 & 4 & 12.9 & \\
\hline & (iii) Clothing & 30 & 96.8 & 1 & 3.2 & \\
\hline \multirow[t]{3}{*}{3.} & Schooling of Kids & 22 & 71.0 & 9 & 29.0 & \multirow{3}{*}{$\begin{array}{l}\text { 2nd } \\
\text { ranked }\end{array}$} \\
\hline & (i) Gov. School & 30 & 96.8 & 1 & 3.2 & \\
\hline & (ii) Public School for Quality Education & 23 & 74.2 & 8 & 25.8 & \\
\hline \multirow[t]{7}{*}{4.} & $\begin{array}{l}\text { House Construction } \\
\text { (i) New House } \\
\text { (a) (Kacha) }\end{array}$ & 22 & 71.0 & 9 & 29.0 & \multirow[t]{7}{*}{$\begin{array}{l}\text { 2nd } \\
\text { ranked }\end{array}$} \\
\hline & (b) Pacca & 28 & 90.3 & 3 & 9.7 & \\
\hline & (ii) House Extension/Repair & & & & & \\
\hline & ( ) Kacha & 29 & 93.5 & 2 & 6.5 & \\
\hline & () Рacca & 28 & 90.3 & 3 & 9.7 & \\
\hline & $\begin{array}{l}\text { (iii) Both Room/kitchen/Repair } \\
\text { ( ) Kacha }\end{array}$ & & & & & \\
\hline & () Pacca & 30 & 96.8 & 1 & 3.2 & \\
\hline 5. & New Agriculture Land Purchased & 26 & 83.9 & 5 & 16.1 & \multirow{5}{*}{$\begin{array}{l}\text { 5th } \\
\text { ranked } \\
\text { 5th } \\
\text { ranked }\end{array}$} \\
\hline 6. & Improved Inputs of Crop Production Purchased & 26 & 83.9 & 5 & 16.1 & \\
\hline 7. & Farm Machinery Purchased & 30 & 96.8 & 1 & 3.2 & \\
\hline 8. & Land Improvement/Development Work & 28 & 90.3 & 3 & 9.7 & \\
\hline 9. & Land Rent & 30 & 96.8 & 1 & 3.2 & \\
\hline 10. & Loan Refunded & 19 & 61.3 & 12 & 38.7 & \multirow{7}{*}{$\begin{array}{l}\text { 1st ranked } \\
4 \text { th } \\
\text { ranked }\end{array}$} \\
\hline \multirow[t]{5}{*}{11.} & Other Investments on & 25 & 80.6 & 6 & 19.4 & \\
\hline & (i) Flour Chaki Venture & 30 & 96.8 & 1 & 3.2 & \\
\hline & (ii) Extension of Nursery/Farming Business & 30 & 96.8 & 1 & 3.2 & \\
\hline & (iii) Health Care & 29 & 93.5 & 2 & 6.5 & \\
\hline & (iv) Purchase of TV etc. & 29 & 93.5 & 2 & 6.5 & \\
\hline 12. & Savings (Cash in Hand) & 30 & 96.8 & 1 & 3.2 & \\
\hline
\end{tabular}

\section{REFERENCES}

Ahmed, B., Hussain, Z., and J. Longmire (1993) Farm Management Handbook. Islamabad: Printed at PanGraphic (Pvt.) Ltd.

Altimir, O. (1982) The Extent of Poverty in Latin America. (Word Bank Staff Working Paper 522.)

Dasgupta, A. K., and D. W. Pearce (1979) Cost-Benefit Analysis: Theory and Practice. Hong Kong: The Macmillan press Ltd. 
Davidson, B., Bashir Ahmad, and M. A. Chaudhry (1996) Estimating the Extent of Poverty in the Mixed Farming Zone of the Punjab. A Report prepared for the Agricultural Social Sciences Research Centre, Faculty of Agricultural Economics and Rural Sociology, University of Agriculture, Faisalabad, Pakistan.

Federal Bureau of Statistics (1999) Household Income Expenditure Survey. Statistical Division, Government of Pakistan, Published by the Manager of Publications, Karachi.

Hussain, H. (1988) Credit for Alleviation of Rural Poverty. IFPRI, USA. (Research Report No. 65.)

Khan, M. A., et al. (1999) Baseline Survey of Livestock Management in Rainfed Farming Systems of Pothwar and Shakargarh Punjab. Pak. German Technical Cooperation (GTZ) Social Sciences Institute, NARC and Social Sciences Division, Pakistan Agricultural Research Council, Islamabad.

Khan, M. H. (1987) Rural Poverty in Bangladesh, India and Pakistan: Profiles and Policies. The Pakistan Development Review 26:3, 309-340.

Mohmand, A. G. (1999) Micro-enterprise Development in Mountain Areas: A Review of NGO Initiatives in Pakistan. ICIMOD, Katmandu, Nepal.

Pakistan, Government of (2001) Economic Survey, 2000-2001. Government of Pakistan, Economic Adviser's Wing, Finance Division, Islamabad.

Qureshi, S. K., and G. M. Arif (1999) Micro Impact of Macro Adjustment Policies: Profile of Poverty in Pakistan, 1998-99. Pakistan Institute of Development Economics, Islamabad.

Saeed, I., and M. Nasir (2001) Onion Seed Production and Marketing in Malalkand Division: Division: Opportunities and Constraints of Certified Growers. Directorate of Agribusiness Relations, Social Sciences Division, Pakistan Agricultural Research Council, Islamabad.

Sen, A. K. (1976) Poverty: An Ordinal Approach to Measurement. Econometrica March, 219-231. 


\section{Comments}

This is one of the few papers which focuses on the analysis of poverty in the remote areas of the NWFP. To mitigate the problem of poverty, the role of only one crop is analysed in the present paper.

The causes of poverty are deep-rooted, ranging from acute income inequalities to severe social and economic injustice. Increase in per capita income, provision of social justice, and reduction in the incidence of poverty have been the slogans of each and every government.

A number of studies with reference to agriculture have been done in Pakistan, where head count and poverty gap indices have been used to estimate the poverty of the tillers of the soil. The conclusion of the current paper is that onion seed production instead of onion bulb production is proving better to tackle the poverty problem. Recommended farm and agricultural practices are more efficient to reduce the menace of poverty.

I have some general observations on the paper, which may be imparted in the revised version.

(1) Perhaps the greatest of all the problems with measuring economic development is that GNP and income per capita say nothing at all about the distribution of the output and income. Unequal distribution of income and resources within a country/region effect welfare negatively in several fairly obvious ways. The Gini coefficient estimates provide the basic insight information about the distribution of income. If possible such estimates about the study area can be incorporated in the paper.

(2) Poverty is a multidimensional concept and the factors responsible for its incidence are numerous. To understand the different aspects of poverty new indices such as Human Development Index, Human Poverty Index and Poverty of Opportunity Index are considered better and are able to highlight the situation in a better way. Because a number of governmental organisations were involved in the onion seed production project, therefore, the data required for these indices may be available with the authors. If available data permits, the employment of the above-mentioned indices, can enhance the scope of the study.

(3) There are some inbuilt deficiencies in the head count and poverty gap indices. For example, poverty gap index does not reflect change in the degree of severity of poverty, if income distribution among the poor becomes more unequal with mean income remaining unchanged. Similarly 
some value judgment is involved in the selection of poverty measure. To avoid this value judgment and to overcome the deficiencies of head count and poverty gap index, Foster, Greer and Thornbacks (FGT) class of additively decomposable poverty measure can be employed. Head count ratio and poverty gap index are special cases of FGT index but FGT has few more qualities as its sensitivity can be altered.

(4) Division of households into poor and non-poor is classificatory and depends upon value judgment. Definitions of poor and non-poor and findings of Table 5 are contradicting each other's. In every literature, availability of drinking water, dwelling status, availability of electricity are the indicators of development. Table 5 shows that poor household have 13 percent, 7 percent and 79 percent more access to drinking water, dwelling and electricity respectively as compared to non-poor households.

(5) The authors have reported estimates in various tables. However, these table have not been properly explained particularly the results of Table 5 need more explanations.

At the end, authors need appreciation for their efforts and contributions.

University of Arid Agriculture,

Abdul Qayyum Mohsin

Rawalpindi. 